\title{
THE APRIL MEETING IN NEW YORK
}

The seven hundred thirty-fourth meeting of the American Mathematical Society was held at the Biltmore Hotel in New York, New York, from Sunday, April 11, through Wednesday, April 14, 1976. There were 387 registrants including 290 members of the Society.

By invitation of the Committee to Select Hour Speakers for Eastern Sectional Meetings, there were three one-hour addresses. W. Wistar Comfort of Wesleyan University spoke on Ultrafilters: some old and some new results; he was introduced by Peter J. Freyd. John S. Lew of the IBM T. J. Watson Research Center spoke on Some applications of structural concepts in asymptotic analysis; he was introduced by James G. Glimm. Robert MacPherson of Brown University spoke on Characteristic classes for singular spaces; he was introduced by Hyman Bass.

John F. Kennison of Clark University organized a special session on Sheaves and Other Topoi; speakers were Norman Auspitz, John F. Kennison, Christiane Rousseau, Lawrence Stout.

G. S. Ladde of SUNY at Potsdam organized a special session on Applicable Differential Equations; speakers were S. R. Bernfeld, Kuang-Ho Chen, Paul William Davis, R. D. Driver, J. Eisenfeld, Narendra S. Goel, Stephen Grossberg, Thomas G. Hallam, Stuart Hastings, James L. Kaplan, William Kilmer, G. S. Ladde, S. Leela, Robert Rosen.

Edgar R. Lorch of Columbia University organized a special session on Functional Analysis and Allied Topics; speakers were Lewis A. Coburn, R. G. Douglas, Edward G. Effros, James Glimm, Roger Howe, Shizuo Kakutani, Peter D. Lax, Bertram Yood.

There were eight sessions for contributed ten-minute papers, chaired by Denis L. Blackmore, Edwin K. Gora, Jin Bai Kim, Miriam A. LipschutzYevick, Andrew G. Markoe, Howard Lewis Penn, Steven I. Rosencrans, Joe B. Thrash, Jr.

With the support of the Energy Research and Development Administration and the National Science Foundation, a symposium on Asymptotic Methods and Singular Perturbations was held on Sunday and Monday. This topic was selected by the AMS-SIAM Committee on Applied Mathematics, whose members were Earl A. Coddington, Donald S. Cohen, Richard C. DiPrima, Lester E. Dubbins, J. Barkley Rosser, Stephen Smale, W. Gilbert Strang. The organizing committee consisted of Donald S. Cohen, Joseph B. Keller, Robert E. O'Malley, Jr. (chairman), M. D. Van Dyke. Speakers were: Ellis Cumberbatch, Paul C. Fife, Marvin I. Freedman, G. W. Hedstrom, Frank C. Hoppensteadt, David R. Kassoy, Petar Kokotovič, Heinz-Otto Kreiss, Donald Ludwig, Frank W. J. Olver, Mark A. Pinsky, Keith Stewartson, Wolfgang $\mathrm{R}$. Wasow, David J. Wollkind, Chien $\mathrm{H}$. Wu. The sessions were chaired by Donald S. Cohen, Joseph B. Keller, Martin B. Kruskal, Robert E. O’Malley, Jr., M. D. Van Dyke.

The American Mathematical Society presented a one-day Short Course on Introduction to Computer Science for Mathematicians on Monday. The program was under the direction of Shmuel Winograd of the IBM T. J. Watson Research Center. Lecturers were: Robert L. Constable, Micholas Pippenger, Michael O. Rabin. 
There was a concurrent meeting of the Association for Women in Mathematics, organized by Lenore Blum.

The Council met on Sunday, April 11, 1976 at 5:00 P.M. in Suites L and M of the Biltmore Hotel in New York.

The Council agreed to continue for another year the trial of electing members of the Nominating Committee by the method of the single transferable ballot.

The Council approved publication of an announcement in the Notices (see vol. 23, p. 259, August 1976) concerning the terms under which the Society might undertake to be the institutional affiliate of grant applicants in need of such affiliation.

The Council endorsed in principle a plan, presented by the Committee on Science Policy, for Postgraduate Research Institutes to be held at various institutions of higher learning for a limited time (suggested limits of three to twenty seven months), in various specialized topics, with "senior" and "junior" members in the sense of accomplishment and time since the Ph.D., and with financing to be sought from a granting agency.

The Council recommended a change in the bylaws with the effect of establishing a category of "foreign member", such members to have all the privileges of membership except the right to vote and to have dues not to exceed two-thirds of the dues of an ordinary member. The definition of the category is in the hands of the Council. The amendment, if adopted, is to be effective January 1, 1978. The new category of membership replaces membership by reciprocity, no longer available after 1977.

The Council recommended a change in the bylaws repealing Article IV, Section 8. Among its effects, the repeal denies to the Council the "power to speak in the name of the Society" and erases conditions and rules governing the act. At the same time the Council referred to the Committee on Principles and Procedures the question of when and how to hold a referendum, a question also affected by the proposed repeal.

The Council recommended that presiding officers at meetings of the Council and at Business Meetings follow Sturgis' Standard Code of Parliamentary Procedure, revised.

A Standing Committee on the Agenda for Business Meetings was authorized.

A Committee on Human Rights of Mathematicians was established.

Three persons were elected to the Editorial Board of the Notices for terms of two years, namely Robion C. Kirby, Arthur P. Mattuck, and George Piranian.

Louis N. Howard was nominated to represent the Society on the U.S. National Committee on Theoretical and Applied Mechanics.

The Council made some of the nominations for the election of 1976. For one position of vice-president, they nominated John T. Tate, with at least one more nomination from the Council expected, and possibly nominations by petition. For five positions of member-at-large of the Council, they nominated Theodore W. Gamelin, Richard J. Griego, Karl H. Hofmann, Raymond L. Johnson, Robert P. Langlands, Henry P. McKean, Jr., Martha Kathleen Smith, and W. T. Tutte, with at least two more nominations by petition or by the Council expected. 
The Council had adjourned for dinner from 6:30 P.M. until 8:00 P.M. and finally adjourned after midnight.

Bethelehem, Pennsylvania

Everett Pitcher Secretary

Middletown, Connecticut

WALTER H. GoTTSCHALK

Associate Secretary

\section{THE APRIL MEETING IN RENO}

The seven hundred thirty-fifth meeting of the American Mathematical Society was held at the University of Nevada in Reno, Nevada, on Friday and Saturday, April 23 and 24, 1976. There were 162 registrants, including 126 members of the Society.

By invitation of the Committee to Select Hour Speakers for Far Western Sectional Meetings, there was one invited hour address. Professor Robert T. Powers of the University of Pennsylvania and the University of California, Berkeley, lectured on KMS states of UHF algebras and their application to quantum statistical mechanics. He was introduced by Professor Theodore W. Palmer.

There were four special sessions. Professor Bruce E. Blackadar of the University of Nevada, Reno, organized a Special Session on $C^{*}$-Algebras and Related Topics. The speakers were Bruce A. Barnes, Bruce E. Blackadar, Lawrence G. Brown, Man-Duen Choi, John A. Ernest, Jacob Feldman, Ramesh A. Gangolli, Philip P. Green III, Peter Florin Hahn, J. William Helton, Calvin C. Moore, Marc A. Rieffel, Jonathan Rosenberg, and William M. Scruggs. Professor Peter A. Griffin of California State University, Sacramento, organized a Special Session of thirty-minute talks on Mathematics of Gambling. The speakers were Thomas M. Cover, William H. Cutler, Thomas S. Ferguson, and Peter A. Griffin. Professor Darrell C. Kent of Washington State University organized a Special Session on Convergence Spaces. The contributors were Thomas K. Boehme, Allan C. Cochran, William Alan Feldman, Roman Frič, Ray J. Gazik, James M. Irwin, Darrell C. Kent, Terrence S. McDermott, James F. Porter, Ellen E. Reed, Gary D. Richardson, M. Schroder, and Edwin F. Wagner. The proceedings of these sessions on Convergence Spaces will be published by the University of Nevada. Professor Ralph N. McKenzie of the University of California, Berkeley, organized a Special Session on Varieties of Algebras. The speakers were Kirby A. Baker, John T. Baldwin, George M. Bergman, Alan Day, R. P. Dilworth, George A. Grätzer, Bjarni Jonsson, Peter H. Krauss, George McNulty, Philip Olin, A. Regev, Walter F. Taylor, and Paul M. Weichsel.

There were three sessions of contributed papers. They were chaired by Robert D. Davis, Robert Clark Hooper, and Edward F. Wishart.

The meeting was held in conjunction with a meeting of the Association for Symbolic Logic. The Association scheduled two one-hour talks. Professor Gabriel Sabbagh of the University of Paris VII and the University of California, Berkeley, lectured on First order properties of linear groups and Professor Yiannis N. Moschovakis of the University of California, Los 